\title{
Status Change Model of Interethnic Riots
}

\author{
Sandra Marker \\ School of Behavioral Sciences, Black Hills State University, Spearfish, SD 57783, USA; \\ sandra.marker@bhsu.edu; Tel.: +1-605-642-6239
}

Received: 12 September 2018; Accepted: 5 November 2018; Published: 8 November 2018

\begin{abstract}
The status change riot model opens up a new avenue of riot explanation. One that takes into consideration ethnic group relations and factors of group status and honor-i.e., dignity. The riot model asserts that the potential for a riot arises when new and old concepts about group statuses, and as such, ideas about appropriate intergroup behaviors, give rise to disputative intergroup interactions. The model affirms that a trigger event either by itself or in accumulation with other events drives actors to a dignity threshold that prompts them to riot. The model further relates that, once started, a riot will follow a general riot pattern that ends in either a status resolution or an increased strain in ethnic group relations.
\end{abstract}

Keywords: interethnic riot; status; honor; social structure; intergroup relations

\section{Introduction}

A global examination of ethnic group relations makes it clear that violence in the form of interethnic riots punctuates, and, at times, engulfs countries from around the world [1-3]. Notwithstanding the global prevalence of these events, no causal factor has been found that is more than moderately significant and no general process has been established that expresses observed riot behaviors [1,4]. The empirical inadequacy of riot theory may reside in the restricted narrative that is used to explain ethnic riots. Social scientist Steve Reicher [5] (p. 31) notes that:

Throughout history, one of the first casualties of riots has always been scientific understanding. From the French Revolution to modern-day, riots concerted attempts by authorities to limit the way events are explained make empirically grounded understanding virtually impossible.

The delineated riot explanation seemingly leads ethnic riot studies to focus on either the socioeconomic conditions and/or circumstances of one set of actors [6,7], or on rioters' social-psychological factors. Pointedly, although social-psychological theories frame and give meaning to interethnic riot processes, they lack the ability to identify riot causal factors [8]. This is also true for socioeconomic riot theories. After decades of riot research, no socioeconomic factor has been found that is significant to riot causation $[9,10]$. Nonetheless, interethnic riots continue to be rationalized in socioeconomic terms. Social scientist Franck Poupeau [11] (para. 10) underscores this point in his report on the 2005 French riots:

The connection spontaneously established between "urban poverty" and "riots" that most observers presented as a foregone conclusion is far from self-evident, first and foremost because, even though the events were the most spatially extensive and temporally durable case of "unrest" in decades, they did not occur in every sensitive and impoverished area ... other areas have similar unemployment levels and did not "burn".

Horowitz [1] (p. 328) reiterates, "for every [ethnic] riot in conditions of hardship" there is "another riot in conditions of abundance". This and other findings reported in the riot literature indicate that only "one conclusion can be clearly drawn [about riot theories]: existing theoretical formulations of the action crowd do not hold up well against the close scrutiny of more systematic empirical inquiry" [4] (p. 874). 
This paper presents a status change model of interethnic riots that moves riot explanation from the delimited economic order ${ }^{1}$ to the wider social order. ${ }^{2}$ It does so by defining actors as members of status groups rather than as members of social classes. ${ }^{3}$ This delineation aligns with riot literature findings that report rioters are members of ethnic groups that are composed of individuals from all socioeconomic classes [2,13]. The riot model's status group definition also allows for the concept of social identities (e.g., ethnic, gender) to be examined. A concept that is central to social identity theory [8] that presumes individuals both define themselves and act not on only the basis of their distinct personal identity, but also on the basis of their group identity (e.g., ethnicity, gender). Social scientists, Clifford Stott, John Drury, and Steve Reicher [8], further argue that the concept of social identities is the factor that enables individuals to act collectively; it brings with it an awareness that one holds a collective social position as an individual within a group, and as a member of a group in relation to other social groups. This awareness is assumed to arise from situations where individual group members experience similar conditions, such as oppressive practices by state authorities-e.g., the police [8].

The status change riot model builds on social identity theory's premise that social identities (e.g., ethnicity, gender) significantly explain collection action (e.g., ethnic riots). The riot model, in addition, assumes what social identity theory assumes, the factor of social identities is significant to connecting actors' individual behaviors with structural intergroup relational patterns [8]. Relational patterns that ethnic riot studies indicate are fundamental to ethnic riots. For, as Horowitz [1] (p. 12) explains, "[ethnic riots] spring from highly patterned occurrences and conditions and reflect clear-cut structures of racial and ethnic group relations". Group relations that are expressed in terms of riot instigator-target dynamics. Group actions that are played out when members of the instigator group selective target members of a specific group, their representatives (e.g., police, authorities), and/or their property. Horowitz [1] (p. 4) makes plain this point in his study:

[S]elective targeting appears to be practically universal in ethnic riots. In every case, there is more than one potential target group, but in virtually every violent episode one ethnic group is targeted and others are bypassed.

Ethnic riots are thus, defined as intergroup events that exhibit violent collective action against members of a specific ethnic group and/or their property [1,3].

The status group classification of actors further provides the riot model with the ability to account for not only socioeconomic disparities between instigator and target groups, but also for differentials in

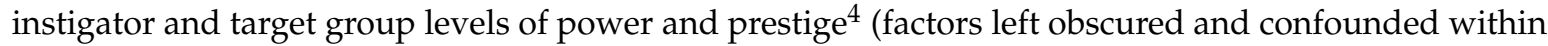
socioeconomic variables). Power is the ability to "realize one's will in a communal action", even when confronted with resistance [12]. Prestige is the amount of social honor a group holds [12]. Social honor is defined as an actor's level of dignity or sense of worth [15]. This includes "one's worth in one's own eyes and [also] in the eyes of others" [16] (p. 17). As such, honor is expressed as a value, an estimate of worth by the individual, and an estimate of worth by society $[17,18]$. In addition, social scientist Julian Pitt-Rivers [17] asserts that honor is also a group factor. It is "an integrated part of a group's social identity" [17] (p. 22). Group honor is delineated as the value or estimate of worth that group members

1 The economic order is defined as "the way in which economic goods and services are distributed and used within a society" [12] (p. 181).

2 Weber (1958) explains that whereas the economic order is comprised of classes, the social order consists of status groups (p. 181). He further adds that "the social order is of course conditioned by the economic order to a high degree, and in its turn reacts upon it" [12] (p. 181).

3 Weber states [12] (p. 193), '“classes' are stratified according to their relations to the production and acquisition of goods, [while] 'status groups' are stratified according to the principle of their consumption of goods as represented by special 'styles of life'". In addition, Weber informs [12] (pp. 186-187), "in contrast to classes, status groups are normally communities that include both propertied and propertyless people".

4 Jim Sidanius and Felicia Pratto [14] (p. 33) in their study of social dominance define hierarchical structures as the amount of "social power, prestige and privilege that an individual possesses by virtue of ... membership in a particular socially constructed group". 
place on the group and that society places on the group. Pitt-Rivers [17] (p. 22) explains, "the right to pride [i.e., honor] is the right to status, and status is established through the recognition of a certain social identity".

Lastly, delineating actors as status group members allows for the status group riot model to bring into examination the intersection that exists between actors' ethnic identity and gender identity. Gender identity, according to social psychologists Sarai Blincoe and Monica Harris [19] (p. 510) is intricately associated with an actor's gender group affiliations that are informed by an awareness of "socially shared stereotypes about men and women", which are reflected in cultural gender roles. Gender identities as such are closely associated with actors' "inclusion and status concerns" [19] (p. 510), as are ethnic identities. Hence, the riot model by identifying actors as status group members brings into examination the intersection of ethnicity, gender, and honor. For, as Pieter Spierenburg [20] (p. 7) asserts, "social stratification is a crucial factor influencing concepts of honor as well as definitions of masculinity". He continues [20] (p. 2), "honor and shame are characteristically gendered. In almost every society, male honor is considered to be quite different from female honor". The definition of male honor, as used in this paper, comes from social scientists who study the concept of honor, Donald A. Saucier, Amanda J. Stanford, Stuart S. Miller, Amanda L Martens, Alyssa K. Miller, Tucker L. Jones, Jessica L. McManus and Mason D. Burns [21] (p. 8): "the belief that male aggression is sometimes appropriate, justifiable, and even necessary as a response to provocation, especially when that provocation insults or threatens a man's manhood". The definition of manhood encompasses concepts of masculinity that are associated with courage (e.g., a man should not be afraid to fight), pride in manhood (e.g., if a man does not defend himself, he is not a very strong man), socialization (e.g., as a child you were taught that boys should always defend themselves), virtue (e.g., physical violence is the most honorable way to defend yourself), and provocation (e.g., if a man is insulted, his manhood is insulted) [21] (p. 14).

The unique characteristics of male honor versus female honor arises from the hierarchical gender system. Social scientists Jim Sidanius and Rosemary Veniegas [22] (p. 54) explain that the form of the tiered gender system is "maintained by socializing women and men into distinct roles". Roles that personify culturally shared expectations that are associated with social perceptions of masculinity and femininity [22]. This process genders honor in that male honor embodies concepts of masculinity and female honor exemplifies concepts of femininity. The masculine qualities of male honor, as stated above, promote aggressive behavior and arouse males to defend their manhood [21]. The status change riot model contends male honor with its underlining qualities of masculinity and dignity, may be significant with regard to explaining the often-overlooked general riot finding, males participate in riots at rates that are significantly higher than females [1,2,13].

\section{Riot Model's Theoretical Foundations and Assumptions}

The foundations for the status change riot model are derived from sociologist Anthony Giddens's structuration theory and anthropologist Victor Turner's four-stage social drama design. Giddens's structuration theory gives the status change model the ability to explain interethnic riots in terms of macro-micro relationships that exist between social structures and individuals' conscious actions or agency [23]. ${ }^{5}$ Turner's social drama design provides the riot model with a causal condition-i.e., status change, and a general riot processional pattern.

The riot model assumes that socially constructed and maintained hierarchical group structures are comprised of ethnic status groups, of which rioters are members. Giddens [24] asserts social structures can be analyzed as "rules and resources" because "[p]ower is an integral element of all social life" as are social meanings and norms. As such, structures can be examined in terms of the resources (e.g.,

5 Giddens [24] (p. 20) asserts, "agency arises from the actor's knowledge of schemas, which means the ability to apply them to new contexts". 
social patterns, practices, beliefs) that "are being drawn upon" to construct and maintain inequitable "power relations" [24] (p. 28). Giddens [24] (pp. 455-456) expounds:

All social interaction involves the use of power as a necessary implication of the logical connection between human action and transformative capacity. Power within social systems can be analyzed as relations of autonomy and dependence between actors in which these actors draw upon and reproduce structural properties of domination.

Social scientists Anthony Giddens and Christopher Pierson [25] emphasize that the power, meaning, and norms that give form to social structures are also what give form to society. They exclaim, "society only has form, and that form only has effects on people, insofar as structure is produced and reproduced in what people do" [25] (p. 77). Social scientists Jim Sidanius and Felicia Pratto [14] (p. 44) additionally report in their work on social dominance, "social hierarchy is not maintained primarily by the oppressive behavior of dominates, but by the deferential and obsequious behavior of subordinates".

The riot model, which is based on the above stated premises about social structures, presumes that hierarchical group arrangements have an in-built or inherent characteristic of inequality that is signified by a rank-order configuration [14]. A framework that tells ethnic group members they are not equally valued in society. Each group's position within the tiered structure is assumed by the riot model to communicate to its group members their comparative social worth-i.e., their social status. Status is the amount of wealth, power and prestige that an individual or group possesses or controls that is expressed in terms of status honor [12]. Status honor contains within it concepts of respect, esteem, stature, dignity, and so on. What is more, the source of status honor is acknowledged as arising from an act of usurpation, an action that involves the taking, appropriating, seizing, and/or commandeering of wealth, and power and/or prestige from another person or group [12]. ${ }^{6}$ Honor consequently "implies not merely a habitual preference for a given mode of conduct, but the entitlement to a certain treatment in return" [17] (p. 22).

The riot model additionally assumes that group inequities that are expressed by the hierarchical framework that characterizes group structures imparts to ethnic group members expectations about intergroup interactions. ${ }^{7}$ The riot model supposes that members of higher positioned groups, due to being in an upper location in the social structure, expect from members of lower positioned group members greater levels of respect, esteem, deference, courtesy, and so on, than they do from members of their same group. Correspondingly, members of groups that are situated near the bottom of the structure are presumed by the model to be socially informed by their group's lower placement in the edifice to be socially obliged to relinquish to members of higher positioned groups a degree of deference that exceeds what is accorded to members of their same group.

Since intergroup interactions involve the giving and taking of social honor, the riot model presumes that they are status situations. A status situation is "every typical component of life that is determined by a specific positive or negative, social estimation of honor" [12] (p. 187). Blincoe and Harris [19] explain that the relationship between interaction and status comes from the social image that we perceive others have of us. Our estimations of honor thus develop as we interpret and give meaning to actions that are aimed toward us. The meanings that we give to these actions are informed by our culture and by our cultural and gendered ideas of honor (e.g., respect, disrespect). Each interaction as such involves the process of estimating our social honor. This process involves interpreting and giving meaning to one's actions and the actions of those with whom one is interacting. Pitt-Rivers [17] (p. 21) further remarks that "[t]he notion of honor is something more than a means of expressing approval or disapproval. It possesses a general structure which is seen in the institutions and customary evaluations".

\footnotetext{
Weber [12] (p. 188) in his classical analysis of status concludes, "usurpation is the normal origin of almost all status honor". Giddens [24] (p. 27) argues, "the structural properties of social systems are embedded in practical consciousness: in 'knowing how to go on' in a whole diversity of contexts of social life".
} 
The riot model presumes actors' intergroup exchanges are a window into how actors' perceive the legitimacy of social structures and the norms they prescribe. If actors adhere to a structure's social dictates, the model assumes the group formation is regarded by the actors as legitimate [14,25]. Correspondingly, if ethnic group members engage in behaviors (e.g., rioting) that do not fit traditional norms ${ }^{8}$ the riot model contends the social structure is considered illegitimate, at least by the nonconforming group members. Giddens [24] (p. 51) stresses that the legitimacy of a social structure is significant in that the structure's influence and power "operates in conjunction" with its "legitimation"; if actors perceive that the structure is justifiable they will engage in behavioral patterns that prolong and reinforce it. Likewise, if actors perceive the structure as illegitimate they will resist or discontinue the normative patterns that up hold it.

Giddens [24] (p. 455) points out that the "inherent relation between production and reproduction" that builds and maintains social structures also carries within it "seeds of change". Attributes that enable "those who are [in a] subordinate" position to "influence the activities" of those who are in an authoritative position [23] (p. 16). Inequity is thus not the only characteristic inherent to hierarchical structures. Change also is an intrinsic aspect of tiered social formations. This is demonstrated by Stott, Drury, and Reicher's finding [8] that indicates riots in general both "reflect" group relations and "transform" them. The influential actions that bring about change are reported by Giddens and Pierson [25] to take place during fateful situations. That is, during circumstances that encourage actors to "react creatively and interpretatively" to the situation at hand [25] (pp. 7-8). Giddens [27] (p. 113) further relates, "there are, of course, fateful moments in the history of collectives as well as in the lives of individuals".

Non-normative actions that bring about change are the product of an individual's agency-conscious choice to act in a prescribed way. ${ }^{9}$ Once an actor makes a conscious decision to break away from established intergroup norms it is difficult for them to revert back to established intergroup conventions [27] (p. 114). This is because breaking a norm constitutes breaking the social agreement that supports the norm. Sociologist Ira Cohen [28] (pp. 83-85) continues:

If there is a disruption in what is taken for granted, either because of changes in external conditions, or thought and reflection on the part of the actor, then there are possibilities for changes in these forms of action. Where these are associated with more than a single actor, on a larger scale or broader basis, such changes can be connected to social change.

\section{Status Change Events}

In view of the fact that rioters act in ways that go against socially prescribed intergroup norms, ethnic riots are presumed by the status change riot model to be events that contain within them seeds of change. Additionally, given that ethnic riots are interethnic events, the riot model supposes ethnic riots are status situations, incidents that involve intergroup exchanges of respect, dignity, and honor. For this reason, the riot model designates interethnic riots as status change events. As occurrences where actors make conscious choices to engage in non-normative actions (i.e., riotous behaviors) that contain the possibility of change. The actors' non-normative behaviors are presumed by the riot model to express the illegitimate view they have of the ethnic group structure and its prescribed intergroup values and norms.

Status change events are occurrences that involve a group of actors who pass from one status (i.e., social position) to another. Anthropologists typically study these types of events that they call rites of passage. Anthropological studies indicate that status change events have a general processional pattern (i.e., ritual) that includes three stages, separation, limen, and reaggregation [29-31]. Separation

8 "Norms are the informal rules that guide what people do and how they live" [26] (p. 89).

9 Sociologists emphasis agency in terms of "an individual's mental abilities and the ways in which these abilities can be used to create important, if not decisive, actions" [26] (p. 18). 
is the initial stage that begins the status change process. During this phase, actors perform symbolic behaviors that signify they have detached from their social position $[30,31]$. The second, or liminal stage, of the status change process is a period of transition. A limen is a threshold. Liminality is a state, as well as a process, of transition. Those undergoing liminality are liminaries, individuals "betwixt and between established states" [32] (p. 63). During the liminal phase, actors behave in ways that are outside customary patterns of behavior. However, it must be noted that research on status change events indicates that although the actors' behaviors during this period do not follow everyday norms, they do adhere to established conventions for this event phase [31]. For example, research indicates that even during status change events that anthropologists call rituals of rebellion where participants express hostility towards one another, the actions and behaviors during the liminal period conform with traditional concepts of conflict behavior [30]. The liminal phase of a status change event is followed by a phase of reaggregation; a stage in which actors rejoin their community, albeit in a new social position [30-32].

In addition to identifying thee general process phases, the studies indicate that there are different types or categories of status change events $[30,31]$. Each type contains the three aforementioned stages as well as an element that distinguishes it from the other event types. Research further indicates that every type of status change event has its own symbolic dialogue and its own distinctive set of behaviors [30]; just as each play has its own script, each event type has a consistency of language and actions in its performance. Subsequently, every time that an event is performed it is in a sense a repetition of itself. The action or scenes are played out in the actors' own style; however, the basic production is ultimately a repetition of each former enactment.

Turner [30] in his extensive examination of status change events identified a type, i.e., social dramas, that has a unique redressive phase. Turner [30] (p. 274) reports that the four-stage social drama takes place in the public domain and displays a "rivalry ... between interest groups for authority, prestige, wealth, and other sources of power". He further relates:

[Social dramas are] units of aharmonic or disharmonic social process, arising in a conflict situation. Typically, they have four main phases. (1) breach of regular norm-governing social relations; (2) crisis, during which there is a tendency for the breach to widen; (3) redressive action ranging from personal advice and informal mediation or arbitration to formal juridical and legal machinery; and, (4) the final phase consists either of the reintegration of the disturbed social group, or of the social recognition and legitimation of irreparable schism between the contesting parties [32] (pp. 63-64).

Lastly, Turner [30] (p. 89) explains that the "outcome of the redressive stage is never certain, and the regression to a state of unresolved crisis is always possible". Therefore, Turner [30] reports that the regressive phase as two possible outcomes, reintegration or irreparable schism.

\section{Status Change Riot Model}

The five-stage riot process (see Figure 1) that was identified by the status change riot model is derived from Turner's [30] social drama. The riot model's stages of status change, riot, response, and status resolved/unresolved correspond with Turner's [30] social drama stages of breach, crisis, redress, and reintegration/schism. The trigger stage of the riot model is the element that makes the riot process distinctive from other types of status change events. This phase consists of an intergroup incident where one or more actors perceives their dignity/honor has been assailed. Lastly, it must be pointed out that what is typically termed to be a riot is recognized by the status change model to be the middle or third stage of the overall five-stage riot process.

Riot studies report riots have a general processional pattern $[1] .{ }^{10}$ Moreover, studies indicate that riots are not merely patterned internally, but that they are also patterned cross-nationally. Horowitz [1]

10 Horowitz [1] (p. 1) concludes, "the deadly ethnic riot is a passionate highly patterned event ... it is not a random phenomenon". 
(p. 14) observes that "there are regularities across riot episodes. These strikingly similar patterns permit a significant measure of generalization about ethnic conflict, not for particular societies alone, but as a general phenomenon". The riot literature reports the following general patterns and characteristics:

- $\quad$ riots are preceded by precipitating incidents $[1,7,33]$;

- $\quad$ riotous activities are set in motion by trigger events $[1,7,33,34]$;

- $\quad$ riots are in general structured by implicit rules and behaviors $[1,7,33]$;

- riots are followed by some type of response to the event [1,33,35]; and,

- males represent a significant percentage of riot actors and targets $[1,2,6]$.

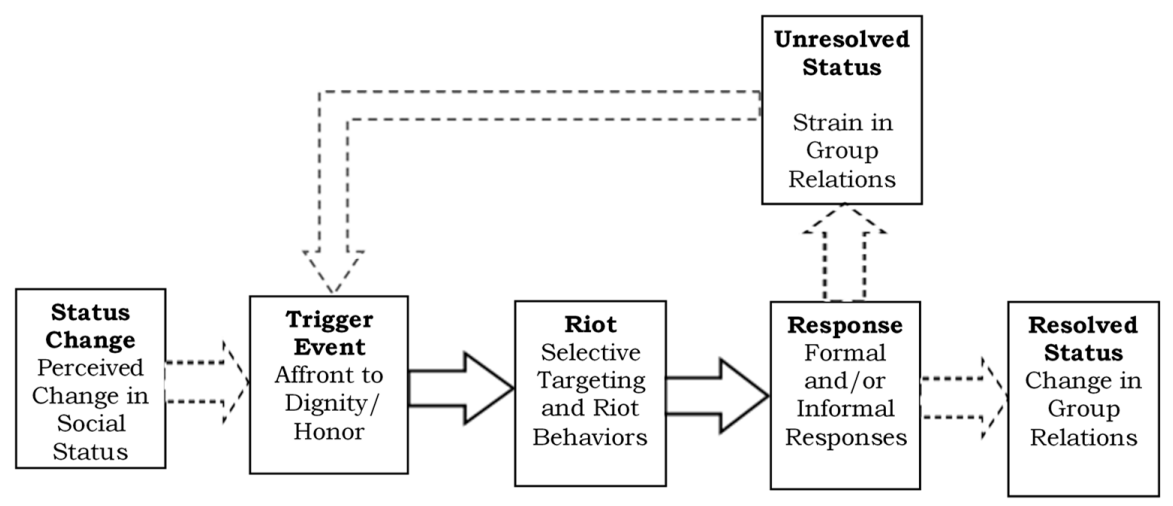

Figure 1. Status Change Riot Model.

\subsection{Phase One-Status Change}

The status change model submits that the first phase of the riot process begins, as do all status change events, with a real or perceived change in status. When a group of actors move away from a social positions or status. The riot model asserts that the first phase of the riot process is initiated when an experience, incident, or condition causes a set of ethnic group members to undergo a real or perceived change in how they view their standing in society. The status change riot model drawing from Giddens's structuration theory, presumes that when a group of actors perceives either an upward or a downward change in their social status they corresponding acknowledge a change in their social level of prestige (i.e., dignity/social honor). Actors, who perceive an upward status change, are presumed by the model to acquiesce lesser amounts of respect, esteem, and so on during interethnic interactions than they did prior to the change. Likewise, the model posits that a recognized downward shift in a group's social position results in the actors conceding a higher level of deference, courtesy, and so on in interethnic situations than they did prior to the status shift.

The perceived status change embodied in the first phase of the riot process is exemplified in the following research that describes the historical conditions that preceded different global periods of rioting. Prior to early twentieth century US riots, the Rosewood Report [35] states African-American Veterans on returning home from World War I (WWI) had a new outlook about their place in American society. The veteran's new sense of status arose from their overseas experiences during WWI where they were treated in a manner that was similar to their white military colleagues. African-American soldiers were given equal responsibilities, equal authority, and equal access to public and military facilities [35]. The report further documents how these experiences empowered the veterans and transformed how they acted in intergroup situations when they returned home to the US at the end of the war:

As events in Chicago [1919 riot] and East St. Louis [1917 riot] made clear, black citizens had changed their attitude ... blacks began to defend themselves against the mounting violence [35] (p. 6).

A similar status change was reflected in mid-twentieth century interethnic Asian and African riots. Throughout this period, ethnic groups in Asia and Africa rejected the lower social ranking that 
colonial powers had assigned to them and demanded sovereignty [1]. Another example of a perceived status change can be found in the US that began with the Civil Rights Movement prior to the1960s urban riots. Sociologist Pamela Oliver [36] (p. 3) observes that "[n]ot only did the majority of blacks feel proud ... their collective sense of ... group pride rose ... [and] continued with the postwar anticolonial struggles in Africa".

Other examples of the first riot phase being indicative of a perceived status change are expressed in the following quotes that describe how the status quo was breaking down prior to early European and US twenty-first century riots. Social scientist Michel Wieviorka [37] (p. 5) describes France during this period as, "facing ... a total crisis where the social, the institutional, the political and the cultural elements ... don't seem to be conciliated". A second illustrative example comes from British social scientists Stephen Reicher and Clifford Scott [38] (para. 13) in their analysis of the 2011 English Tottenham riot: "[it] arose out of an incident that exemplified police illegitimacy ... [actors'] passion reflected not only outrage but also the exultation of those who could finally assert their power over those who normally held power over them".

A last representative example of the riot model's status change phase comes from Alicia Garza a cofounder of the Black Lives Matter (BLM) in the US and Tia Oso, the US national organizer of the Black Alliance for Just Immigration. Their quotes illustrate that, prior to the 2014 Ferguson riots and the 2015 Baltimore riots, African-Americans' perception of their group social status was incongruous with that of society's perception. Garza explains that she started the BLM in 2012 "to dismantle systemic racism ... [and] to build a strategy that helps us [i.e., African-Americans] get us from where we are to where we deserve to be" quoted in [39] (para. 8). Oso similarly states that she began her alliance because "[social] reforms are not enough ... the system must be transformed ... to change social norms" quoted in [39] (para. 14).

The riot model asserts that the social atmosphere becomes ripe for riots when members of one or more ethnic groups undergoes a perceived change in status that is not generally recognized and/or accepted. The ripeness increases as perspectives about ethnic group statuses become more divergent in society. This occurs when one set of ethnic group members perceives a status change has occurred, and as such, demand a change in intergroup norms. While during the same time another group of actors contrastingly expects intergroup behaviors to continue as they have in the past. The different set of actors' diverse status perceptions creates an atmosphere that transforms everyday interethnic interactions into portentous status situations-interethnic incidents where the process of estimating the amount of honor-and, as such, worth that is expressed during the event becomes heightened. Consequently, even trivial or benign intergroup interactions during this riot phase can manifest into highly charged intergroup clashes. For example, Horowitz [1] relates how various riot instigators and supporters justified attacks against target group members, because they perceived the target group's attitude as inappropriate; it did not correspond with the instigator group's perception of how the target group should behave:

Black victims were said in Chicago (1919), Detroit (1943), and East St. Louis (1917) to have grown 'arrogant and to 'deserve what they get' ... Bengalis in Assam (1960) were said to be condescending; the violence was justified because of their ... false pride [1] (pp. 368-369)

Social scientist James Messerschmidt [40] in his research on gender, race, and violence describes an example of divergent group perspectives. He reports that after the legal and social status of African-Americans was repositioned in the late nineteenth century, "the definitions and practices outlining both race and masculinity" were in flux and "white male mob violence emerged as an attempt to forcibly re-establish the old meanings and hierarchy" [40] (p. 26). Similarly, social scientist Lee Williams [13] (p. 1), in his research on US riots that ranged from 1906 to 1947 reported, "[the riots] came about because of the compelling urge [of whites] to maintain Anglo-Saxon supremacy". Oliver [36] also reports findings that indicate there were ethnic group divisions about status prior to 1960s US urban riots. She explains: 
[B]lack consciousness underwent a shift ... Although these changes had little direct effect on blacks' economic conditions or political power, they had tremendous impact on the patterns of social interaction in integrated settings [36] (p. 25)

\subsection{Phase Two-Trigger}

The second, or trigger phase of the status change riot model marks the point at which the potential for a riot is actualized via a trigger event $[1,3]$. A trigger event takes place in a public and involves members of two or more status groups and/or their representatives (e.g., police). The intergroup members also have divergent ideas about their social positions, and, as such, about the amount of dignity that they as well as members of other ethnic groups should accede during intergroup interactions. In addition, the trigger phase involves an incident that either by itself or in accumulation with previous intergroup incidents brings the actor/s to a consequential dignity or honor point. Reicher and Scott [38] explain, "[p]eople are predisposed to riot when they have a sense of being treated illegitimately" (para. 6). Wieviorka [37] (p. 3) gives a general example of a trigger event in his report of what caused the 2005 French riots:

In France (but one could compare for instance to Los Angeles in 1992), riots very often start with the news or the rumor of a police or justice misconduct... A second element was also important: the vocabulary used ... promising to clean popular areas from delinquency with a Karcher (high pressure cleaner). These expressions ... were perceived by the youth ... as disqualifying all of them ...

Everyday perceived status slights can also compound overtime and result in a trigger event. Pitt-Rivers [17] (p. 28) explains, "[t]he victim of an affront is dishonoured only at the point where he is forced to recognize that he has been". Specific examples that exemplify typical intergroup interactions that erupted into trigger events come from the 1965 Watts riot that reported as beginning after an African-American man was stopped by the police and barred from entering a local restaurant [33]. The 1967 Atlanta riot was reported as beginning when police arrested an African-American man for allegedly driving while intoxicated [41] and the 1967 Detroit riot was reported as starting in the immediate aftermath of a 21-year-old African-American being arrested for speeding [33].

The concept of honor presents the riot model with the ability to explain why some riots erupt from ordinary or everyday situations while others are triggered by unique events. The factor of dignity or social honor may also be important in explaining why males both represent a significant percentage of riot actors [1,2,10] and riot targets [1]. Messerschmidt [40] concludes in his research that the concept of masculinity in many cultures is associated with the action of defending group honor. For this reason, the riot model suggests males may participate in riots at higher rates than females, because riot participation conforms to societal concepts of masculinity that are expressed in male honor. This postulation is supported by findings in the riot literature. Examples of supportive findings include the following comments made by community members about the 1960s US urban riots: "[Riot communities] saw children respect their fathers for the first time" [42] (p. 91); "[The riot] made our males men" [42] (p. 91). A more contemporary example that reports an association between masculinity, honor and riots comes from social scientist Oliver Roy. He explains that the male youth culture in the 2005 French riot areas where "based on violence and infightings with the police" [43] (para. 5). This conforms to Pitt-Rivers [17] (p. 29) findings that indicate for some cultures "the ultimate vindication of honour lies in physical violence". With regard to explaining how honor relates to research findings that indicate males are targeted in interethnic riots at significantly higher rates than females [1] (p. 73), German historian Ute Frevert [44] (p. 2) observes that "[n]otions of honor and shame are characteristically gendered ... men may take pride in attacking fellow men".

\subsection{Phase Three—Riot}

The riot phase of the status change riot model consists of a period of selective targeting $[1,45]$. This is exemplified by reports that state during the 1950 Singapore riot Europeans and Eurasians were disproportionally targeted. Actors damaged property, "mainly automobiles", stole items, and engaged 
in "personal assaults" against Europeans and Eurasians that in some cases ended in death [1] (p. 60). A second example of selective targeting is related in the Rosewood Report [35]. Findings from the Report indicate that only the homes of African-Americans were burned during the 1923 Rosewood riot [35]. Reicher and Scott [38] offer contemporary examples of selective targeting that occurred in the 2011 English riots. They report, "police [who are representatives of the status quo] were pelted with stones, but others (such as fire officers) were largely left alone. Police vehicles were torched, whereas other cars were largely left untouched" [38] (para. 12).

Just as Turner reports that social dramas have rules and patterns, social scientist Carl Couch [46], in his study of crowds, argues that collective behavior is rarely innovative; riots "are not senseless explosions in which anything and everything becomes possible" [38] (para. 3). Rather, interethnic riots exhibit similar patterns and actions [1,7]. Typical riot behaviors include throwing objects, setting fires, overturning vehicles, destroying or defacing property, looting, and in some instances, murder [1,7,33]. Wieviorka [37] offers an example of typical riot behaviors in his description of the 2005 French riots. He states, "[actors were] setting fire to private cars ... targeting public institutions ... schools, for instance, and also buses [37] (para. 1). The onset of the Detroit riot as reported to researchers is another example that conveys conventional riot actions, "[m]embers of the crowd began hurling rocks at passing cars ... overturning cars and setting them on fire" [33] (p. 37).

\subsection{Phase Four-Response}

The fourth phase of the riot process corresponds with Tuner's social drama phase of redress. This phase of the riot process involves responses to the riot stage. Responses can be official, from legal and/or governmental sources, or, alternatively, they can be unofficial comments, statements, or conjectures. Official responses reported in the riot literature include punitive actions against rioters (e.g., arrests, fines, incarceration), and reactive actions to the riot (e.g., public meetings, unofficial and official inquiries, changes in local, state, or federal laws, policies, and/or practices). Unofficial responses consist of social commentaries about the riot. The literature finds that unofficial responses include statements or interpretations of the riot by local and national leaders, remarks by state and local law enforcement officials and/or commentaries by local community members [1,33]. An example of a formal response followed in the aftermath of the 1921 Tulsa, Oklahoma riot. A Grand Jury was formed to investigate the cause of the riot, and any criminal actions that may have occurred during the incident [47]. Similarly, in the aftermath of the 1960s, US urban riots Lyndon Johnson established a presidential commission to find out what caused the riots and what could be done to mitigate these types of events. An example of an unofficial response comes from social scientist Franck Poupeau's [11] (para.1) description of what occurred subsequent to the 2005 French riots, "specialists of the 'social question' crowded the screens, airwaves, and newspapers to describe the scope of the 'suburban crisis'".

\subsection{Phase Five-Status Resolved/Unresolved}

The status change model indicates that the last stage of the riot process status resolved/unresolved is consistent with Turner's social drama phase of reintegration/schism. The final riot process stage ends in one of two possible outcomes, either in a resolved disagreement about a group's status, or in an increased strain between the groups due to not resolved group status issues. For, as Horowitz [1] (p. 11) states, "one thing it [the riot] will not do is to leave the conflict where it was". The resolution in status outcome occurs when divergent views about actors' ethnic group statuses coalesce into a new socially agreed upon viewpoint; this occurs when the greater part of society regards the social position of the acting groups, and, as such, group members, in a similar way. For example, in the late 1960s, the city of Atlanta enacted new employment laws in response to the Civil Rights Movement and to widespread US urban riots. The wage change both increased the earnings of African-American city workers in Atlanta and, as such, implicitly increased the workers' level of wealth, power and prestige (i.e., their status). Over time, these and other nondiscriminatory practices were accepted in Atlanta 
and across the US. This led to the simultaneous transformation of US ethnic group structures and US interethnic interactions.

The status change riot design conversely indicates that the unresolved outcome of the riot model occurs when actors' perceptions about ethnic group statuses remain divergent $[7,48,49]$. This situation is exemplified by Perez, Berg, and Myers [49], who report that following the 1960s Boston and San Francisco riots both communities displayed strong divisions along racial lines. The Rosewood Report [35] gives a similar finding following the 1923 Rosewood Riot, stating that the brutality and intensity of the riot divided African-Americans and European-Americans for nearly 70 years.

The status change model indicates that the status nonresolution outcome of the last riot phase, as does the first stage, contains within it the potential for a riot. The potential arises out of the same atmosphere described in the initial riot phase, a divisive perception about ethnic group standings that can precipitate contentious status situations. Just as in the first phase of the riot process, discordant perceptions surrounding ethnic group standings generate within the status nonresolution outcome, a ripe atmosphere for riots. The status change model emphasizes that the potential for a riot can exist for days, weeks, and even decades during this riot process phase. The status nonresolution outcome of the last phase of the status change riot model thus presents a mechanism for explaining a general riot study finding, riots reoccur in the same geographic places over short and long periods of time $[1,33]$. Roy's [43] (para. 1) statement about the 2005 French riots exemplifies this finding, "[i]t came as no surprise, they [the riots] have been recurrent since the early 1980's". Spilerman's [7] (p. 636) findings offer another example, "eleven of 15 cities experienced two or more disturbances during 1965-1968".

The riot potential in the status nonresolution outcome of the final riot phase can be triggered by a status event, just as it can in the initial status change riot phase. If a new riot is ignited, then the status change model indicates that it will follow the same processional process as previous riots. The triggering event is followed by the riot stage, response stage, and status resolution/nonresolution phase. The model further discloses that the riot process can continue to loop through the different riot stages until such time that the response phase of the riot process results in the status resolution outcome of the status resolution/nonresolution phase. At this point, the potential for a riot dissipates and the social atmosphere is no longer highly predisposed to unsettled intergroup status situations due to a perceived social agreement about ethnic groups' social standings.

\section{Conclusions}

The status change riot model opens up a new avenue of riot explanation. One that identifies riots as status change events. This provides the riot model with the ability to explain riots in terms of ethnic group relations and factors of group status and honor-i.e., dignity. The status change model additionally points out that the riot process both begins and ends with change. It begins with a transformation in the actors' perception of their social standing and ends with either an alteration to ethnic group structures and interethnic norms, or an increased strain in ethnic group relations.

Further studies are needed to test the general viability of the riot model and the strength of its descriptive and explanatory power. Additionally, studies are needed to understand the significance of honor in explaining the gendered aspects of riots and other violent collective events. Furthermore, research is essential to answering important questions about the significance of status in terms of social change. Can the model be used to explain intergroup violence in general? For, as Horowitz [1] (p. 12) reports, [e]thnic riots are a frequent forerunner of secessionist warfare, of terrorism and of several major forms of political change". Do violent intergroup events involve on one or more group of actors who engage in purposeful action in an attempt to disrupt social hierarchies and/or norms in order to transform their place in society or the world?

Funding: This research received no external funding.

Conflicts of Interest: The author declares no conflicts of interest. 


\section{References}

1. Horowitz, D. The Deadly Ethnic Riot; University of California Press: Berkeley, CA, USA, 2001.

2. Gilje, P. Rioting in America; Indiana University Press: Bloomington, IN, USA, 1996.

3. Lieberson, S.; Silverman, A. The Precipitants and Underlying Conditions of Race Riots. Am. Sociol. Rev. 1965, 30, 887-898. [CrossRef] [PubMed]

4. Abudu-Stark, M.; Raine, W.; Burbeck, S.; Davison, K. Some Empirical Patterns in a Riot Process. Am. Sociol. Rev. 1974, 39, 865-876. [CrossRef]

5. Reicher, S. Reading the Riot Actors. New Sci. 2011, 2830, 30-31. [CrossRef]

6. McPhail, C. Civil Disorder Participation: A Critical Examination of Recent Research. Am. Sociol. Rev. 1971, 36, 1058-1073. [CrossRef] [PubMed]

7. Spilerman, S. The Causes of Racial Disturbances: A Comparison of Alternative Explanations. Am. Sociol. Rev. 1970, 35, 627-649. [CrossRef]

8. Stott, C.; Drury, J.; Reicher, S. On the Role of a Social Identity Analysis in Articulating Structure and Collective Action: The 2011 Riots in Tottenham and Hackney. Br. J. Criminol. 2017, 57, 964-981. [CrossRef]

9. Finkel, S.; Rule, J. Relative Deprivation and Related Psychological Theories of Civil Violence: A Critical Review. In Social Movements, Conflicts, and Change; Lang, K., Lang, G., Eds.; JAI Press: Greenwood, MA, USA, 1986; Volume 9, pp. 47-69.

10. Olzak, S.; Shanahan, S. Deprivation and Race Riots: An Extension of Spilerman's Analysis. Soc. Forces 1996, 74, 931-961. [CrossRef]

11. Poupeau, F. French Sociology Under Fire: A Preliminary Diagnosis of the November 2005 Urban Riots, Social Science Research Council: 2005 Riots in France. Available online: http:/ / riotsfrance.ssrc.org/Poupeau/ (accessed on 13 January 2015).

12. Weber, M. Class, Status, Party. In From Max Weber: Essays in Sociology; Gerth, H., Mills, C.W., Eds.; Oxford University Press: New York, NY, USA, 1958; pp. 180-195.

13. Williams, L.E. Post-War Riots in America 1919-1946: How the Pressures of War Exacerbated American Urban Tensions to the Breaking Point; Edwin Mellen Press: Lewiston, NY, USA, 1991.

14. Sidanius, J.; Pratto, F. Social Dominance Theory: A New Synthesis. In Social Dominance: An Intergroup Theory of Social Hierarchy and Oppression; Jost, J.T., Sidanius, J., Eds.; Cambridge University Press: New York, NY, USA, 1999; pp. 31-57.

15. Jasso, G. Studying Status: An Integrated Framework. Am. Sociol. Rev. 2001, 66, 96-124. [CrossRef]

16. Rodriguez Mosquera, P.M.; Manstead, A.; Fischer, A. Honor in the Mediterranean and Northern Europe. J. Cross Cult. Psychol. 2002, 33, 16-36. [CrossRef]

17. Pitt-Rivers, J. Honour and Social Status. In Honour and Shame: The Values of Mediteranean Society; Peristiany, J.G., Ed.; Weidenfeld and Nicolson: London, UK, 1965; pp. 19-77.

18. Barrett, F.; Sarbin, T. Honor as a Moral Category: A Historical-linguistic Analysis. Theory Psychol. 2008, 18, 5-25. [CrossRef]

19. Blincoe, S.; Harris, M.J. Status and Inclusion, Anger and Sadness: Gendered Responses to Disrespect. Eur. J. Soc. Psychol. 2011, 41, 508-517. [CrossRef]

20. Spierenburg, P. Masculinity, Violence and Honor: An Introduction. In Men and Violence Gender, Honor, and Rituals in Modern Europe and America; Spierenburg, P., Ed.; Ohio State University Press: Columbus, OH, USA, 1998; pp. 1-29.

21. Saucier, D.; Stanford, A.; Miller, S.; Martens, A.; Miller, A.; Jones, T.; McManus, J.; Burns, M. Masculine Honor Beliefs: Measurement and Correlates. Personal. Individ. Differ. 2016, 94, 7-15. [CrossRef]

22. Sidanius, J.; Veniegas, R.C. Gender and Race Discrimination: The Interactive Nature of Disadvantage. In The Claremont Symposium on Applied Social Psychology Reducing Prejudice and Discrimination; Oskamp, S., Ed.; Lawrence Erlbaum Associates Publishers: Mahwah, NJ, USA, 2000; pp. 47-69.

23. Giddens, A. The Constitution of Society: Outline of the Theory of Structuralism; University of California Press: Berkeley, CA, USA, 1984.

24. Giddens, A. A Contemporary Critique of Historical Materialism, Vol.1, Power, Property and the State; Macmillan: London, UK, 1981.

25. Giddens, A.; Pierson, C. Conversations with Anthony Giddens: Making Sense of Modernity; Polity: Cambridge, MA, USA, 1998. 
26. Ritzer, G.; Murphy, W.W. Essentials of Sociology, 3rd ed.; Sage Publications: Thousand Oaks, CA, USA, 2018.

27. Giddens, A. Modernity and Self-identity: Self and Society in the Late Modern Age; Polity: Cambridge, MA, USA, 1991.

28. Cohen, I. Theories of Action and Praxis. In The Blackwell Companion to Social Theory, 2nd ed.; Turner, B.S., Ed.; Blackwell: Oxford, England, UK, 2000; pp. 73-111.

29. Gluckman, M. Les Rites de Passage. In Essays on the Ritual of Social Relations; Gluckman, M., Ed.; Manchester University Press: Manchester, UK, 1975; pp. 24-40.

30. Turner, V. The Drums of Affliction: A Study of Religious Processes Among the Ndembu of Zambia; Oxford University Press: Oxford, UK, 1968.

31. Van Gennep, A. The Rites of Passage; University of Chicago Press: Chicago, IL, USA, 1960.

32. Turner, V. Process, Performance and Pilgrimage; Concept Publishing: New Delhi, India, 1979.

33. Report of the National Advisory Commission on Civil Disorders; Kerner, O. (Ed.) Bantam: New York, NY, USA, 1968.

34. McPhail, C.; Wohlstein, R.T. Individual and Collective Behaviors within Gatherings, Demonstrations, and Riots. Annu. Rev. Sociol. 1983, 9, 579-600. [CrossRef]

35. Rosewood Report: A Documented History of the Incident Which Occurred at Rosewood, Florida, in January 1923; University of Florida: Tallahassee, FL, USA, 1993.

36. Oliver, P. Bringing the Crowd Back: The Nonorganizational Elements of Social Movements. RSMCC 1989, 11, 1-30.

37. Wieviorka, M. Violence in France. Social Science Research Council: 2005 Riots in France. Available online: http:/ / riotsfrance.ssrc.org/Wieviorka (accessed on 13 January 2015).

38. Reicher, S.; Scott, C. Mad Mobs and Englishmen? Myths and Realities of the 2011 Riots. The Guardian. Available online: http:/ / www.theguardian.com/science/2011/nov/18/mad-mobs-englishmen-2011-riots (accessed on 13 January 2015).

39. Workneh, L. The Unrelenting Fight for Black Lives 25 Years After the LA Riots. Black Voices. Available online: http:/ / www.huffingtonpost.com/entry/black-lives-justice-la-riots_us_5902dab3e4b0bb2d086c73b9 (accessed on 28 April 2017).

40. Messerschmidt, J. Crime as Structured Action Gender, Race, Class, and Crime in the Making; Sage: Thousand Oaks, CA, USA, 1997.

41. Hill, G. Curfew Ordered. New York Times. Available online: http://partners.nytimes.com/library/national/ race/081565race-ra.html (accessed on 13 January 2015).

42. Hacker, F.; Harmetz, A. The Riot: A Liberating, Identifying Force. In Urban Racial Violence in the Twentieth Century; Boskin, J., Ed.; Glencoe: Beverly Hills, CA, USA, 1969; pp. 87-92.

43. Roy, O. The Nature of French Riots," Social Science Research Council: 2005 Riots in France. Available online: http: / / riotsfrance.ssrc.org/Roy/ (accessed on 13 January 2015).

44. Frevert, U. Taming of the Noble Ruffian: Male Violence and Dueling in Early Modern and Modern Germany. In Men and Violence, Gender, Honor, and Rituals in Modern Europe and America; Spierenburg, P., Ed.; Ohio State University Press: Columbus, OH, USA, 1998; pp. 37-63.

45. Feagin, J.; Hahn, H. Ghetto Revolts: The Politics of Violence in American Cities; MacMillan: New York, NY, USA, 1973.

46. Couch, C. Collective Behavior: An Examination of Some Stereotypes. Soc. Probl. 1968, 15, 310-322. [CrossRef]

47. Tulsa Race Riot Jury Indicts Police Chief. New York Times, 19 June 1921; 16.

48. Bergesen, A. Race Riots of 1967 an Analysis of Police Violence in Detroit and Newark. J. Black Stud. 1982, 12, 261-274. [CrossRef]

49. Perez, A.D.; Berg, K.; Myers, D. Police and Riots, 1967-1969. J. Black Stud. 2003, 2, 153-182. [CrossRef]

(C) 2018 by the author. Licensee MDPI, Basel, Switzerland. This article is an open access article distributed under the terms and conditions of the Creative Commons Attribution (CC BY) license (http:/ / creativecommons.org/licenses/by/4.0/). 